\title{
IMPLEMENTASI MANAJEMEN KURIKULUM \\ DI SMP AISYIYAH BOARDING SCHOOL MALANG
}

\section{TESIS}

\section{Untuk Memenuhi Sebagian Persyaratan}

Memperoleh Derajat Gelar S-2

Program Studi Magister Kebijakan dan Pengembangan Pendidikan

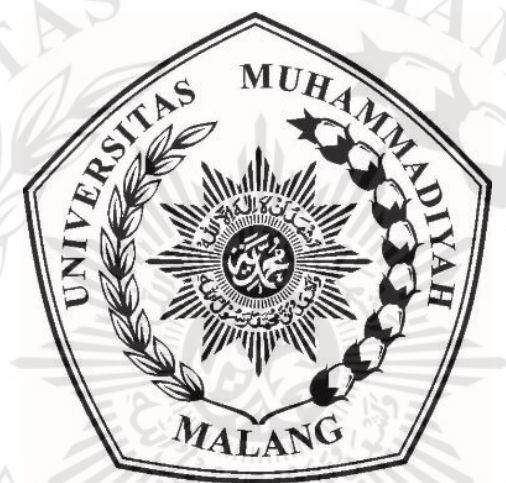

Disusun Oleh:

HASTIM ROSIANA

NIM. 201810240211016

DIREKTORAT PROGRAM PASCASARJANA

UNIVERSITAS MUHAMMADIYAH MALANG 


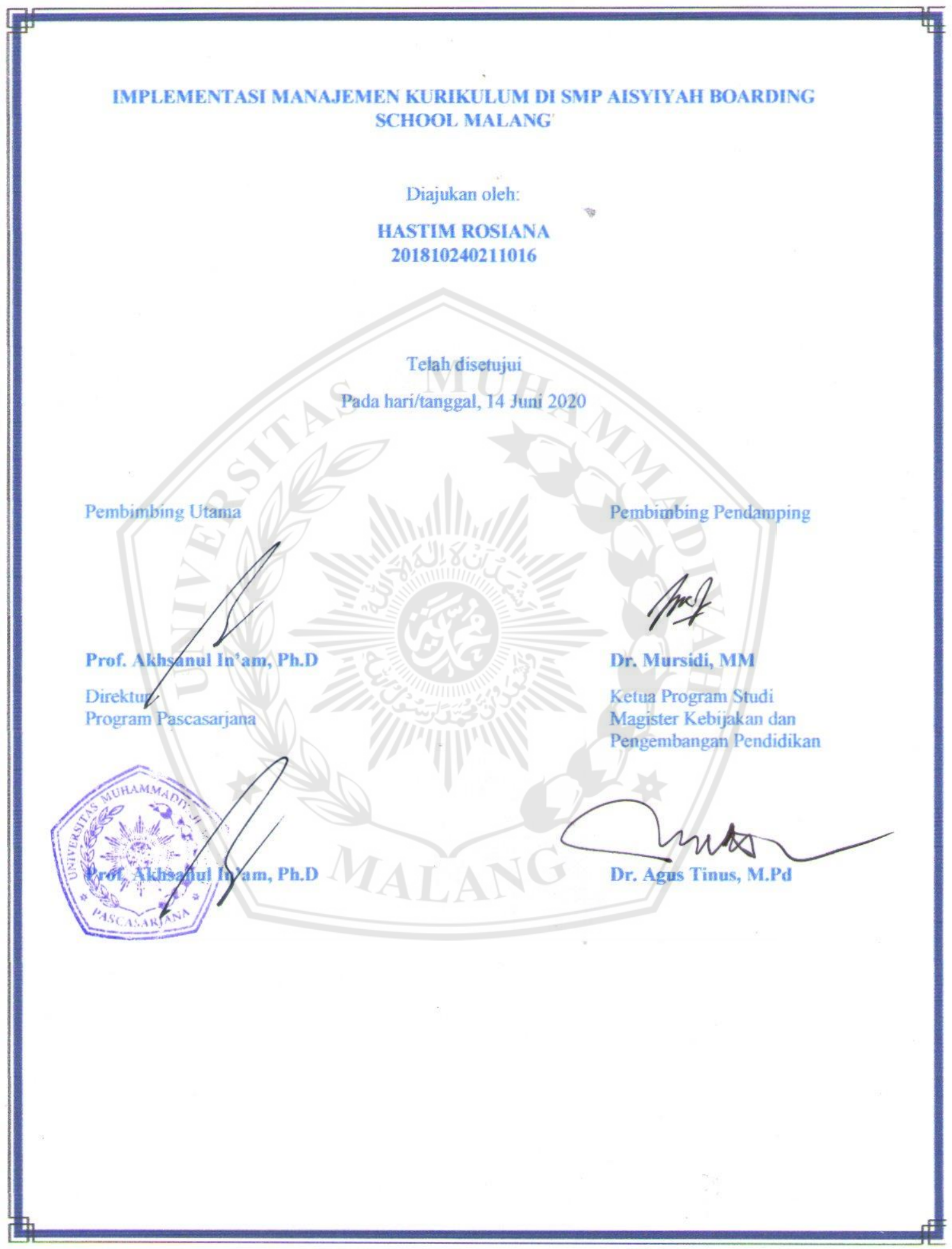




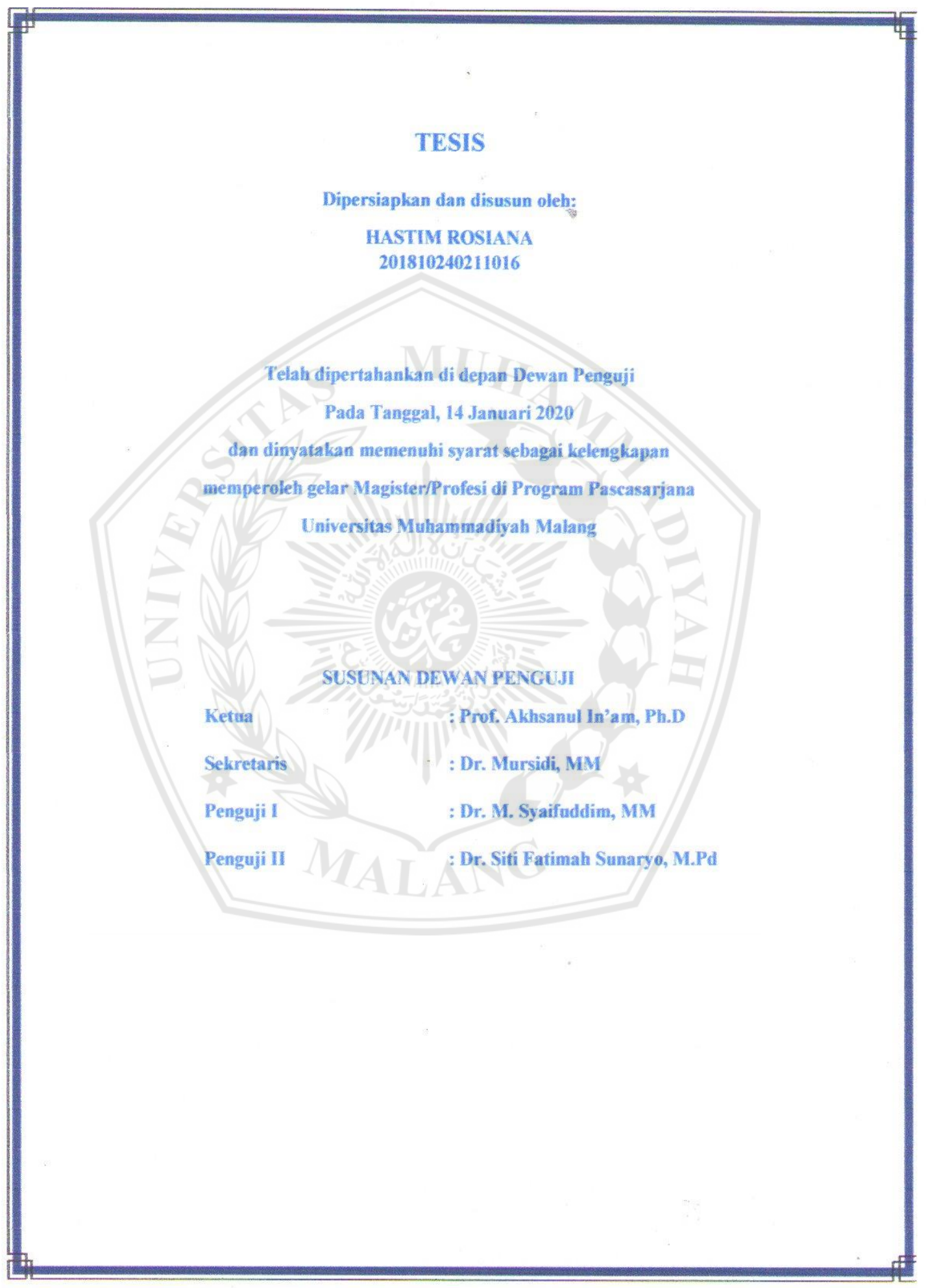




\section{SURAT PERNYATAAN}

Nama

NIM

Program Studi
: HASTIM ROSIANA

201810240211016

: Magister Kebijakan dan Pengembangan Pendidikan

Dengan ini menyatakan dengan sebenar-benarnya bahwa :

1. TESIS dengan judul : IMPLEMENTASI MANAJEMEN KURIKULUM DI SMP

AISYIYAH BOARDING SCHOOL MALANG. Adalah karya saya dan dalam naskah Tesis ini tidak terdapat karya ilmiah yang pernah diajukan oleh orang lain untuk memperoleh gelar akademik di suatu Perguruan Tinggi dan tidak terdapat karya atau pendapat yang pernah ditulis atau diterbitkan oleh orang lain, baik sebagian maupun keseluruhan, kecuali yang secara tertulis dikutip dalam naskah ini dan disebutkan dalam sumber kutipan dalam daftar pustaka.

2. Apabila ternyata dalam naskah Tesis ini dapat dibuktikan terdapat unsur-unsur PLAGIASI, saya bersedia Tesis ini DIGUGURKAN dan GELAR AKADEMIK YANG TELAH SAYA PEROLEH DIBATALKAN, serta diproses sesuai dengan ketentuan hukum yang berlaku.

3. Tesis ini dapat dijadikan sumber pustaka yang merupakan HAK BEBAS ROYALTY NON EKSKLUSIF.

Demikian pernyataan ini saya buat dengan sebenarnya untuk dipergunakan sebagaimana

mestinya.

Malang, 14 Januari 2020

Yang menyatakan,

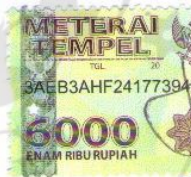

HASTIM ROSIANA 


\section{KATA PENGANTAR}

Syukur alhamdulillah penulis ucapkan kepada Allah SWT yang telah melimpahkan rahmat serta karunia-Nya sehingga Tesis yang berjudul "Implementasi Manajemen Kurikulum di SMP Aisyiyah Boarding School Malang” ini dapat terselesaikan.

Penyelesaian Tesis ini tidak terlepas dari petunjuk arahan dan bimbingan serta dukungan yang diberikan oleh dosen pembimbing serta bantuan dari berbagai pihak. Oleh karena itu, pada kesempatan ini dengan segala kerendahan hati dan rasa hormat, penulis menyampaikan terima kasih sebesar-besarnya kepada:

1. Prof. Akhsanul In'am, Ph.D, selaku Direktur Program Pascasarjana Universitas Muhammadiyah Malang yang memberikan perijinan untuk penulis melakukan penelitian.

2. Dr. Agus Tinus, selaku Ketua Program Studi Magister Kebijakan dan Pengembangan Pendidikan Universitas Muhammadiyah Malang yang memberikan kesempatan penulis untuk menulis Tesis.

3. Prof. Akhsanul In'am, Ph.D, selaku pembimbing I yang telah berkenan meluangkan waktu, tenaga, pikiran dalam membimbing dan memberi pengarahan kepada penulis, sehingga Tesis ini dapat terselesaikan dengan baik.

4. Dr. Mursidi, M.M., selaku pembimbing II yang telah berkenan meluangkan waktu, tenaga, pikiran dalam membimbing dan memberi pengarahan kepada penulis, sehingga Tesis ini dapat terselesaikan dengan baik.

5. Seluruh dosen Program Studi Magister Kebijakan dan Pengembangan Pendidikan yang telah memberikan ilmu pengetahuan pada penulis selama menjadi mahasiswa.

6. Pimpinan Wilayah Aisyiyah, Ibu Asmah, Ibu Sugiarti, Ibu Rukmini yang dengan penuh semangat dan keikhlasan membimbing penulis selama masa penyusunan tesis, serta memberikan masukan dan tambahan ilmu pengetahuan yang tiada ternilai.

7. Seluruh keluarga besar SMP AISYIYAH BOARDING SCHOOL MALANG, terutama Bu Heni selaku Kepala Sekolah ABSM.

8. Seluruh keluarga besar SD Aisyiyah Kota Malang, yang sangat pengertian dan selalu mendukung penulis selama masa penyusunan tesis.

Dengan keterbatasan pengalaman, ilmu, serta pustaka yang ditinjau, penulis menyadari bahwa dalam penulisan Tesis ini masih sangat jauh dari kata sempurna, sehingga saran dan kritik akan selalu penulis harapkan untuk memperbaiki Tesis ini. Akhir kata penulis memohon maaf yang sebesar-besarnya jika dalam proses pembuatan Tesis ini penulis melakukan kesalahan baik yang disengaja maupun tidak disengaja.

Malang, 14 Januari 2020

Penulis 


\begin{abstract}
Abstrak
Rosiana, Hastim. (2020). Implementasi Manajemen Kurikulum di SMP Aisyiyah Boaring School Malang. Tesis. Magister Kebijakan dan Pengembangan Pendidikan. Universitas Muhammadiyah Malang. Pembimbing: 1) Prof. Akhsanul In'am, Ph.D (NIDN : 0710086401), 2) Dr. Mursidi, M.M. (NIDN 0710115701). Email : hastimrosiana@gmail.com
\end{abstract}

Tujuan penelitian ini untuk mengetahui bagaimana fungsi manajemen kurikulum di SMP Aisyiyah Boarding School Malang. Penelitian ini merupakan penelitian kualitatif jenis deskriptif, dengan teknik pengumpulan data berupa dokumentasi, observasi, dan wawancara. Berdasarkan hasil penelitian menunjukkan bahwa dalam penerapan kurikulum di SMP ABSM mengintegrasikan kurikulum nasional, kurikulum pesantren, dan kurikulum Muhammadiyah yang dilakukan secara penuh demi menghasilkan lulusan yang berstandar nasioanal, berwawasan aqidah, ahlaq, dan fiqih sesuai tuntutan Qur'an dan Sunnah. Manajemen kurikulum yang dilaksanakan di SMP ABSM meliputi proses; 1) perencanaan (penentuan visi, misi, dan tujuan yang disesuaikan dengan 3 kurikulum yaitu kurikulum nasional, kurikulum pesantren dan kurikulum khas Muhammadiyah) ; 2) pengorganisasian (mencakup bagian-bagian kegiatan atau program yang diperlukan untuk mencapai tujuan, dan membagi tugas sesuai dengan tugas kerjanya masingmasing); 3) pelaksanaan (dalam pelaksanaannya mengintegrasikan antara kurikulum nasional yaitu KTSP dan K13, kurikulum pesantren dan kurikulu Muhammadiyah) ; 4) evaluasi (evaluasi yang dilaksanakan terkait program sekolah secara keseluruhan dan dilaksanakan setiap sebulan sekali sedangkan evaluasi yang terkait dengan pelaksanaan kurikulum dilakukan setiap hari karena di dalam RPP guru terdapat refleksi untuk evaluasi).

Kata Kunci: Manajemen, Kurikulum, dan Boarding School 


\begin{abstract}
Rosiana, Hastim. (2019). Implementation of Curriculum Management in SMP Aisyiyah Boarding School Malang. Thesis. Master of Education Policy and Development. University of Muhammadiyah Malang. Supervisor: 1) Prof. Akhsanul In'am, Ph.D (NIDN : 0710086401), 2) Dr. Mursidi, M.M. (NIDN 0710115701). Email : hastimrosiana@gmail.com
\end{abstract}

The purpose of this study was to determine how the curriculum management function in Aisyiyah Boarding School in Malang. This research is a descriptive qualitative research, with data collection techniques in the form of documentation, observation, and interviews. Based on the results of the study showed that in the application of the curriculum at SMP ABSM integrated the national curriculum, the pesantren curriculum, and the Muhammadiyah curriculum which was carried out in full in order to produce graduates with national standards, aqidah, ahlaq, and fiqh according to the demands of the Qur'an and Sunnah. The curriculum management implemented at SMP ABSM covers the process; 1) planning (determination of vision, mission, and goals that are adjusted to 3 curricula, namely the national curriculum, pesantren curriculum and Muhammadiyah's unique curriculum); 2) organizing (including parts of activities or programs needed to achieve goals, and dividing tasks according to their respective work assignments); 3) implementation (in its implementation integrating the national curriculum, namely KTSP and K13, the pesantren curriculum and the Muhammadiyah curriculum); 4) evaluation (evaluations carried out related to the overall school program and carried out once a month while evaluations related to curriculum implementation are carried out every day because in the teacher's lesson plan there are reflections for evaluation).

Keywords: Management, Curriculum, and Boarding School 


\section{Daftar Isi}

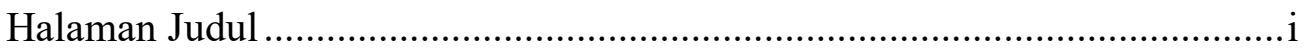

Halaman Persetujuan ................................................................................

Halaman Perngesahan..................................................................................ii

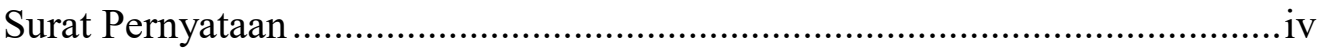

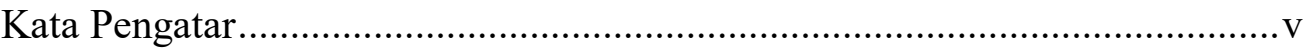

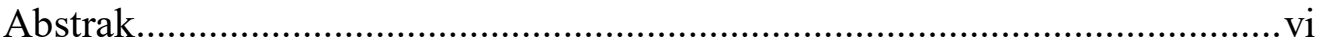

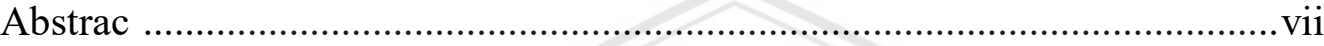

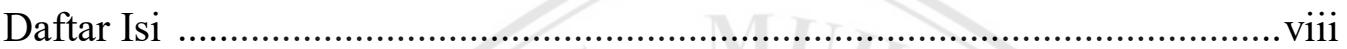

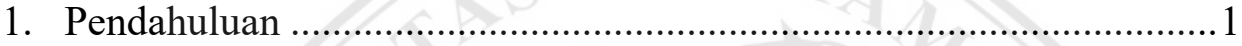

2. Kajian Pustaka ............................................................................ 5

2.1 Manajemen Kurikulum ...........................................................5

2.2 Fungsi Manajemen Kurikulum ................................................. 7

2.3 Konsep Boarding School ........................................................ 10

2.4 Faktor Pendukung Berkembangnya Boarding School................... 11

2.5 Karakteristik Boarding School .................................................. 12

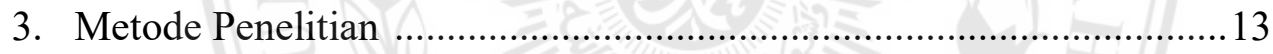

3.1 Pendekatan dan Jenis Penelitian ................................................... 13

3.2 Lokasi dan Waktu Penelitian .................................................... 13

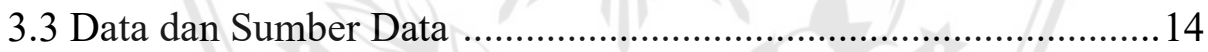

3.4 Teknik Pengumpulan Data ......................................................... 14

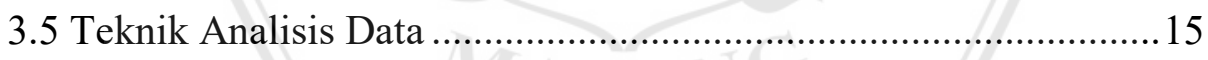

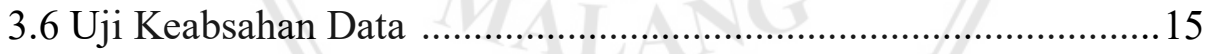

3.7 Tahap-tahap Penelitian ................................................................ 15

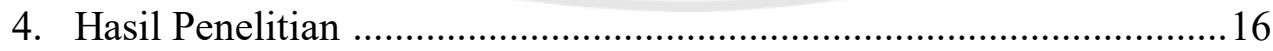

4.1 Perencanaan Kurikulum ............................................................16

4.2 Pengorganisasian Kurikulum...................................................20

4.3 Pelaksanaan Kurikulum ...............................................................21

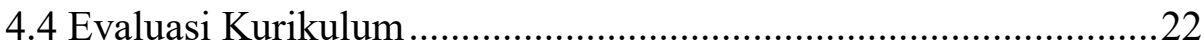

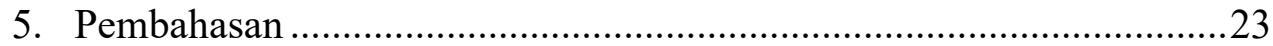

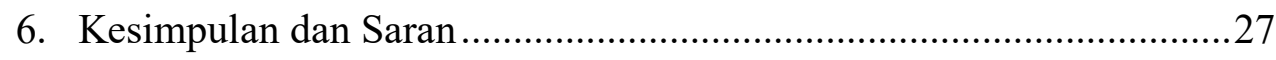

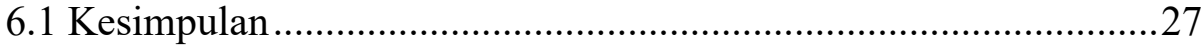

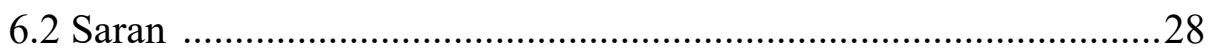

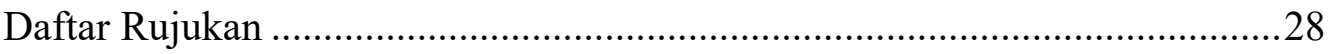




\section{PENDAHULUAN}

Pendidikan merupakan fenomena fundamental atau asasi dalam kehidupan manusia. Sehingga dapat dikatakan, bahwa di mana ada kehidupan manusia, bagaimanapun juga di situ pasti ada pendidikan (Maksudin, 2012; Siswiyo, 1996). Perkembangan kebudayaan manusia, timbullah tuntutan akan adanya pendidikan yang terselenggara lebih baik, lebih teratur dan didasarkan atas pemikiran yang matang dan sistematik. (Priyanto, 2006; Suwadji, 2015). Paradigma baru diperlukan untuk pembaharuan dan pengembangan pengelolaan manajemen lembaga pendidikan, di antaranya adalah sistem pendidikan unggulan berasrama atau dikenal dengan Boarding School .

Hadirnya pendidikan dengan sistem boarding school menjadikan alternatif harapan untuk memberi bekal ilmu pengetahuan dan ilmu agama kepada peserta didik agar dapat memenuhi tuntutan kehidupan (Paminto, Rosiana, \& Budisantoso, 2018). Informasi dan globalisasi seperti yang kita tahu sekarang ini tidak bisa dicegah dan tidak ada pilihan lagi kecuali dengan dengan nilai-nilai agama, akhlak, moralitas, dan karakter. Jadi peserta didik tidak akan menjadi korban informasi dari globalisasi.

Di era globalisasi ini pendidikan pondok pesantren sudah mulai mengalami perubahan dengan inovasi baru yaitu Boarding School yang sebenarnya mengadopsi dari kehidupan Pondok Pesantren, tetapi lebih modern (Ruswanto, 2017). Kehidupan Boarding School yang lebih modern yaitu pola pendidikan yang menggabungkan ilmu pendidikan umum dan ilmu agama Islam serta mewajibkan para siswa untuk belajar mengaji dan bahasa Inggris di lingkungan asrama (Hasan, 2016).

Hadirnya pendidikan yang berpola asrama adalah perpaduan sistem pendidikan umum dengan sistem pendidikan pesantren dimana peserta didik mendapatkan pendidikan selama sehari penuh. Pendidikan ini menawarkan keunggulan yang diukur dari sisi kesiapan peserta didik agar menjadi insan yang beriman dan bertakwa serta mampu untuk hidup mandiri dalam lingkungan masyarakat dimanapun ia berada, bukan saja hanya dirumah, disekolah, atau di lingkungan sekitar rumahnya (Pertiwi, 2017). 
Pendidikan pesantren bertujuan untuk membentuk manusia yang memiliki kesadaran tinggi akan ajaran Islam yang membicarakan tiga masalah pokok, yaitu Tuhan, manusia dan alam. Hasil yang diharapkan memiliki kompetensi tinggi untuk mengadakan responsif terhadap tantangan dan tuntutan hidup dalam konteks ruang dan waktu yang ada (Fathurrochman, 2017).

Menurut Cookson and Persell (2008) Boarding School adalah bentuk pendidikan intensif, tempat siswa tinggal sekolah, dan kunjungi keluarga mereka hanya untuk akhir pekan dan liburan (Behaghel, 2017). Tempat tinggal peserta didik yang jauh dari rumah dipadukan dalam Boarding School mereka disana diajarkan agama sdan pelajaran umum lainnya.

Pola pendidikan di Boarding School pada umumnya memadukan kurikulum nasional dengan kurikulum pesantren. Di antara sekolah yang menerapkan konsep boarding school, ada yang menginduk ke Kementrian Pendidikan dan Kebudayaan (Kemendikbud) dan ada yang menginduk ke Kementrian Agama (Kemenag). Pendidikan Boarding School mendidik kemandirian siswa, hal ini dapat dimaklumi karena hidup di asrama yang jauh dari keluarga menuntut siswa-siswi untuk mandiri dan lebih dewasa (Yatimah, 2011).

Sekolah dikatakan berhasil dalam menjalankan segala aktifitas pembelajaran ditentukan oleh beberapa faktor pendukung. salah satu faktor tersebut adalah faktor manajemen yang diselenggarakan oleh sekolah. Karena manajemen merupakan unsur penting dalam pelaksanaan setiap program organisir kegiatan sekolah (Fikri \& Ferdinan, 2013)

Pelaksanaan Boarding School pada penelitian Maksudin di SMP Islam terpadu Abu Bakar Yogyakarta seolah dikatakan baik jika sesuai dengan visi, misi dan tujuan sekolah. Dengan melalui visi, misi dan tujuan sekolah bisadapat melihat bagaimana Sistem sekolah asrama yang sudah dilaksanakan sudah sesuai dengan tujuan awal didirikanya sekolah dengan sistem Boarding School (Maksudin, 2012).

Manajemen Boarding School ini sebenarnya bukan hal yang baru bagi dunia pendidikan karena sudah ada penelitian terdahulu yang meneliti tentang Boarding School di pedesaan Cina dan menyatakan bahwa kehidupan siswa di asrama mempunyai keunggulan yaitu siswa yang tinggal di asrama memiliki nilai akademik yang lebih bagus dibandingkan dengan siswa yang belajar di sekolah umum dan 
mayoritas siswanya berasal dari keluarga ekonomi menengah kebawah, kebanyakan siswa yang tinggal di asrama mengalami depresi yang cukup tinggi serta kesehatan siswa kurang terjamin karena lingkungan asrama (Yin et al., 2014).

Penelitian di SMA Taruna Palembang Indonesia pelaksanaan program sekolah berasrama untuk mengedukasi moral siswa dengan memadukan pendidikan formal dan program pendidikan agama. Kedua program itu diterapkan dengan pengobatan preventif dan preventatif (Hendriyenti, 2014).

SMP Aisyiyah Boarding School Malang (ABSM) merupakan salah satu lembaga pendidikan yang menerapkan sistem Boarding School atau asrama. SMP ABSM dalam manajemen kurikulumnya telah memadukan antara kurikulum nasional, kurikulum pesantren, dan kurikulum khas sekolah yaitu kurikulum Muhammadiyah.

Boarding School di SMP ABSM sudah dikelola dengan baik, menyikapi kaitannya dengan manajemen Boarding School sangat penting untuk dibahas dan diteliti bagaimana pelaksanaanya dalam mewujudkan sekolah yang unggul sesuai dengan visi misi yang telah tetapkan. Proses manajemen, terdapat fungsi manajemen yaitu perencanaan, pengorganisasian, pelaksanaan dan evaluasi agar tujuan organisasitercapai dengan efektif dan efisien. (Machali, 2012).

Keberhasilan suatu lembaga pendidikan dalam menjalankan segala aktivitas pembelajaran ditentukan oleh beberapa faktor pendukung, dan salah satu faktor pendukung tersebut adalah faktor manajemen yang diselenggarakan oleh lembaga/institusi yang bersangkutan (Machali, 2012). Upaya pengelolaan maupun pengembangan manajerial lembaga pendidikan merupakan suatu keniscayaan yang harus ada dan tidak dapat ditiadakan. Penerapan manajemen pendidikan adakalanya menghadapi berbagai kendala/ hambatan, baik yang bersifat ekonomi-finansial, potensi-intelektual, input - output pendidikan maupun aspek manajerial pengelolaan lembaga hingga pada rendahnya standar mutu pendidikan.

Penelitian mengenai sekolah berasrama atau boarding school sudah banyak dilakukan. Salah satunya penelitian dari Faridah, Arismunandar, Bernard dalam penelitiannya berfokus pada pengelolaan pendidikan akademik dan kehidupan keasramaan di sekolah berasrama. Hasil dari penelitian mereka bahwa sekolah berasrama dianggap lebih baik dibanding non-berasrama. 
Penelitian lain dilakukan oleh Thofek Dian S mengenai Manajemen Kurikulum di SMP Muhammadiyah Boarding School Prambanan Sleman Yogyakarta hasil penelitiannya menunjukkan bahwa; 1) merencanakan dan merumuskan perpaduan antara KTSP dengan kurikulum agama, dengan model kurikulum terpadu; 2) pengelolaan kurikulum menjadi dua yaitu kurikulum umum dan bagian kurikulum agama; 3) implementasi pelaksanaan kurikulum tingkat sekolah dan pelaksanaan kurikulum tingkat kelas; 4) evaluasi kurikulum meliputi evaluasi terhadap guru, evaluasi pembelajaran, dan administrasi (Dian, 2016).

Penelitian-penelitian yang disebutkan itu memperlihatkan begitu banyak aspek pengelolaan di sekolah berasrama. Semakin bertambahnya jumlah sekolah berasrama yang di Indonesia belum diikuti dengan kebijakan pengelolaan sekolah khususnya sekohah berasrama.

Perbedaan penelitian ini dengan penelitian-penelitian yang telah dilakukan sebelumnya adalah penelitian ini hanya berfokus pada fungsi manajemen dalam kurikulum boarding school di SMP ABSM. Diharapkan dengan penelitian ini dapat menemukan karakteristik kurikulum pendidikan dalam perkembangan pendidikan berasrama di Indonesia, baik dari segi kurikulum formal, kurikulum pesantren dan kurikulum khas sekolah, maupun dalam sistem pengelolaannya.

Berdasarkan permasalahan di atas, fokus penelitian dapat dirumuskan sebagai berikut : bagaimana fungsi manajemen kurikulum yang diterapkan di SMP ABSM? 


\section{KAJIAN PUSTAKA}

\subsection{Manajemen Kurikulum}

Kurikulum adalah seperangkat rencana dan aturan menegnai tujuan, isi, dan bahan pelajaran serta cara yang digunakan sebagai pedoman penyelenggaraan kegiatan pembelajaran untuk mencapai tujuan pendidikan tertentu (Rusman, 2018).

Di sekolah kegiatan kurikulum lebih mengutamakan untuk merealisasikan dan merelevansikan kebutuhan daerah dan kondisi di sekolah yang bersangkutan, sehingga kurikulum tersebut merupakan kurikulum yang integritas dengan peserta didik maupun dengan lingkungan sekolah (Rusman, 2018; Sista, 2017).

Munculnya model sekolah yang berbasis pondok pesantren akibat faktor dari penduduk di Indonesia yang mayoritas beragama Islam. Saat ini pendidikani semakin berkembang dan masyarakat mengakui akan keberadaan pendidikan itu sendiri. Dengan sistem boarding school, peserta didik, guru dan pengelola sekolah tinggal di pesantren yang berada dalam lingkungan sekolah.Menurut (Paminto et al., 2018). Sistem boarding school peserta/didiknya bukan hanya mempeoleh pendidikan formal yang berasal dari pemerintah, tetapi juga peserta didik mendapatkan pendidikan agama melalui sistem pembelajaran di sekolah.

Kurikulum boarding school terintegrasi akan menghasilkan output yang unggul dalam aspek-aspek. Secara intelektual mereka akan mampu bersaing dan berkompetisi dengan sekolah lain, sedangkan dari segi agama mereka akan mampu dan memahami, serta mengamalkan secara benar sesuai dengan tuntunan agama (Paminto et al., 2018). Langkah-langkah pengembangan kurikulum boarding school antara laian: 1) Diagnosis kebutuhan kurikulum yang disusun agar peserta didik mampu belajar dengan baik. Karena beragam latar belakang peserta didik maka perlu dilakukan diagnosis; 2) Merumuskan tujuan pendidikan peserta didik untuk mendapatkan petunjuk dalam merumuskan tujuan pendidikan peserta didik agar menjadi manusia yang berkarakter, dan beriman kepada Tuhannnya (Paminto et al., 2018).

Pelaksanaan kurikulum boarding school merupakan suatu gerakan aksi yang dilakukan oleh sekolah dalam kegiatan pembelajaran agar dapat berjalan dengan baik, efektif dan efisien sesuai perencanaan yang terkait dengan keseluruhan mata pelajaran yang disampaikan kepada peserta didik. Perencanaan program atau 
kegiatan pembelajaran yang sudah direncanakan terdapat faktor penghambat atau kendala-kendala teknis yaitu yang berkaitan dengan sarana pembelajaran yang tidak mampu untuk disiapkan atau diadakan sesuai dengan rencana. Faktor inilah yang baisanya sering mengganggu dalam proses atau kegiatan pembelajaran. (Fathurrochman, 2017).

Prinsip yang harus diperhatikan dalam melaksanakan manajemen kurikulum ialah ; 1) produktivitas, aspek yang harus dipertimbangkan dalam manajemen kurikulum adalah bagaimana peserta didik mencapai hasil belajar sesuai dengan tujuan kurikulum; 2) demokratisasi, untuk mencapai tujuan kurikulum harus berdasarkan demokrasi dalam menempatkan pengelola, pelaksana, dan subyek didik dalam melaksakan tugas dengan penuh tanggung jawab; 3) kooperatif, adanya kerja sama yang positif dari berbagai pihak yang terlibat agar diperoleh hasil yang diharapkan; 4) efektifitas dan efisien, untuk mencapai tujuan kurikulum yang memberikan hasil daya guna dengan biaya, tenaga, dan faktu yang relatif singkat harus memperhatikan efektifitas dan efisiensi; 5) mengarahkan visi, misi, dan tujuan yang ditetapkan dalam kurikulum. (Rusman, 2018)

Kurikulum merupakan hal yang paling diperhatikan dalam sistem pendidikan di Indonesia. Begitu pula dalam hal manajemen kurikulum merupakan langkah awal dalam menjalankan kurikulum agar lebih efektif, efisien, dan optimal dalam memberdayakan berbagai sumber belajar, pengalaman belajar, maupun komponen kurikulum. Secara umum fungsi manajemen kurikulum: 1) pemanfaatan sumber daya kurikulum untuk meningkatkan efisiensi; 2) keadilan dan kesempatan kepada peserta didik untuk mencapai hasil yang maksimal; 3) relevansi dan efektivitas pembelajaran sesuai dengan kebutuhan peserta didik maupun lingkungan sekitar peserta didik; 4) efektivitas kinerja guru maupun aktivitas peserta didik dalam mencapai tujuan pembelajaran semakin meningkat; 5) untuk meningkatkan efektivitas dan efisiensi proses belajar mengajar; 6) meningkatkan partisipasi masyarakat untuk membantu mengembangkan kurikulum. (Fathurrochman, 2017)

Manajemen Kurikulum dikatakan berhasil apabila faktor sumber daya manusianya mulai dari pimpinan sampai pelasana kurikulum didukung oleh sumbersumber yang lain, seperti sarana dan prasaran, biaya, waktu, teknologi dan kemampuan manjerialnya. 


\subsection{Fungsi Manajemen Kurikulum}

Fungsi-fungsi manajemen adalah elemen-elemen dasar yang selalu ada dan melekat di dalam proses manajemen yang akan dijadikan acuan oleh manajer dalam melaksanakan kegiatan untuk mencapai tujuan. Namun terdapat perbedaan pandangan mengenai fungsi-fungsi manajemen oleh beberapa ahli. Fungsi-fungsi manajemen meliputi perencanaan, pengorganisasian, pengarahan dan Pengendalian (Hasibuan, 2015; Syafroni Ladzi, 2012).

Perencanaan adalah sebuah proses perdana ketika hendak melakukan pekerjaan baik dalam bentuk pemikiran maupun kerangka kerja agar tujuan yang hendak dicapai mendapatkan hasil yang optimal. Menurut Hasibuan fungsi perencanaan yang terpenting adalah bagaimana menetapkan tujuan atau sasaran yang memadukan dan mengkoordinasikan kegiatan-kegiatan yang diperlukan secara efektif dan efisien (Hasibuan, 2015).

Perencanaan dari masing-masing fungsi adalah proses mempersiapkan serangkaian pengambilan keputusan untuk dilakukannya tindakan dalam mencapai tujuan-tujuan organisasi dengan atau tanpa menggunakan sumber-sumber yang ada. (Usman, 2012).

Suatu perencanaan yang baik harus mencakup unsur-unsur perencanaan yaitu; 1) mengidentifikasi segala sesuatu yang akan dilakukan; 2) merumuskan faktor-faktor penyebab dalam melakukan tindakan; 3) menentukan tempat atau lokasi; 4) menentukan waktu pelaksanaan tindakan; 5) menentukan pelaku yang akan melakukan tindakan; dan 6) menentukan metode pelaksanaan tindakan (R.Terry, 2010)

Tipe-tipe perencanaan dari suatu manajemen mencakup perencanaan jangka panjang, jangka pendek, perencanaan strategi, operasional, tetap dan sekali pakai. Perencanaan jangka panjang digunakan untuk jangka waktu 5 tahun atau lebih dan jangka pendek digunakan untuk jangka waktu satu samapai dua tahun. Sedangkan perencanaan operasioanal sekali pakai digunakan hanya sekali untuk situasi yang unik (Tepy, 2017).

Perencanaan kurikulum merupakan hal yang penting dikembangkan sebagai pedoman yang berisi petunjuk jenis dan sumber individu yang dilakukan, pembiayaan, tenaga sarana yang diperlukan untuk menunjang proses pembelajaran, 
dan monitoring agar tercapai tujuan lembaga serta sebagai pendorong agar sistem pendidikan teracapai hasil yang optimal (Arikunto, 2017). Perencanaan kurikulum merupakan langkah awal pelaksana kurikulum membuat keputusan dan mengambil tindakan untuk menghasilkan perencanaan yang akan digunakan oleh guru dan peserta didik.

Perencanaan kurikulum harus memperhatikan tujuan kurikulum, isi kurikulum, dan stategi pembelajaran. Perencanaan kurikulum yang disusun harus memperhatikan pengalaman peserta didik, isi dan proses, keputusan tentang isu dan topik, melibatkan banyak kelompok, dilaksanakan pada berbagai tingkatan dan sebagai proses yang berkelanjutan (Wahyudin, 2014).

Fungsi Manajemen selanjutnya adalah pengorganisasian. Pengorganisasian ini mencakup bagian-bagian kegiatan atau program yang diperlukan untuk mencapai tujuan, dan membagi tugas kepada manajer untuk mengadakan dan membuat struktur organisansi, dan menetapkan wewenang kepada anggota organisasi. Pada fungsi ini yaitu pengorganisasian berhubungan erat dengan manusia, sehingga penugasannya ke dalam unit-unit organisasi dimasukan sebagai bagian dari unsur organisasi (R.Terry, 2010).

Menurut Sudjana, dalam Ali Khudrin pengorganisasian itu mengumpulkan dan membuat penyususnan semua sumber organisasi yang rencanakan dalam perencanan. Aktifitas dalam membentuk organisasi mencakup sumber daya manusia yang mengefektif dan mengefisienkan sumber daya lainnya untuk menjalankan kegiatan atau program yang telah direncanakan untuk menggapai tujuan yang ditetapkan (Khudrin, 2008)

Pengorganisasian kurikulum merupakan strategi atau desain bahan kurikulum yang tujuannya memudahkan peserta didik mempelajari bahan dalam melakukan kegiatan belajar agar tujuan pembelajaran tercapai (Wahyudin, 2014). Bentuk organisasi dari kurikulum mencakup kurikulum mata pelajaran, kurikulum bidang studi, kurikulum terintegrasi, dan kurikulum inti.

Fungsi manajemen selanjutnya adalah pelaksanaan. Pelaksanaan merupakan pusat aktivitas-aktivitas jalannya manajemen. Aktivitas yang mencakup kegiatan seorang manajer yang dilakukan adalah mengawali dan melanjutkan kegiatan yang ditetapkan oleh bagian perencanaan dan pengorganisasi agar dapat tercapai tujuan 
yang diinginkan. Pemimpin berupaya untuk memberikan semangat atau dorongan kepada anak buahnya untuk mengarahkan perbuatannya dengan mengetahui potensi yang ada dalam bawahannya untuk mencapai tujuan yang telah ditetapkan (R.Terry, 2010).

Selain manajer atau pemimpin yang harus memiliki kemampuan memberikan semangat atau dorongan yang kuat, anak buah atau pihak yang dipimpin juga harus memiliki rasa yang kuat untuk selalu bekerjasama. Pemimpin harus pandai dalam mengorganisir agar terjalin kerjasama yang baik, sehingga dalam proses pelaksanaan tercapai tujuan organisasi (Khudrin, 2008). Fungsi pelaksanaan merupakan proses manajemen untuk mewujudkan tujuan yang telah disusun dalam fungsi perencanaan.

Pelaksanaan kurikulum merupakan proses penerapan ide, konsep dan kebijakan kurikulum dalam pelaksanaan pembelajaran sehingga peserta didik mempunyai kompetensi tertentu sebagai hasil interaksi dengan lingkungan (Wahyudin, 2014). Dalam pelaksanaan kurikulum yang perlu dicermati adalah materi kurikulum dan struktur organisasi kurikulum. Menurut Dinn Wahyudin pelaksanaan kurikulum mencakup tiga kegiatan yaitu pengembangan program, pelaksanaan pembelajaran, dan evaluasi.

Lembaga pendidikan dalam pelaksanaan kurikulum ada dua tingkatan yaitu pelaksanaan kurikulum tingkat sekolah dan kurikulum tingkat kelas. Pada tingkatan sekolah yang berperan adalah kepala sekolah sedangkan pada tingkatan kelas yang paling banyak berperan adalah guru (Hamalik, 2013).

Fungsi manajemen yang terakhir adalah evaluasi. Fungsi terakhir yang dijalankan oleh para manajer adalah evaluasi. Setelah tujuan-tujuan ditetapkan, rencana-rencana dirumuskan, pengaturan struktural digambarkan, dan orang-orang dipekerjakan, dilatih, dan dimotivasi masih ada kemungkinan bahwa ada sesuatu yang keliru (Hasibuan, 2015). Untuk memastikan bahwa semua urusan berjalan seperti seharusnya, manajemen harus memantau kinerja organisasi. Kinerja yang sebenarnya harus dibandingkan dengan tujuan-tujuan yang ditetapkan sebelumnya.

Evaluasi kurikulum merupakan tindakan pengendalian, penjaminan, dan penetapan mutu kurikulum (Wahyudin, 2014). Ini salah satu komponen penting dan 
tahap yang harus di tempuh oleh guru dalam penngembangan kurikulum. Evaluasi sebagai tolok ukur keberhasilan atau kegagalan dalam perencanaan kurikulum.

\subsection{Konsep Boarding School}

Pendidikan pesantren telah diadopsi ke dalam sistem pendidikan nasional. Gejala ini terlihat jelas pada sekolah-sekolah unggulan/ Boarding School sejak tiga dasa warsa terakhir. Sekarang banyak bermunculan sekolah unggulan menerapkan sistem pesantren meskipun dibungkus dengan nama lain boarding school, sekolah internal, atau yang lain. Jadi sekolah berasrama (boarding school) mengadopsi pendidikan pesantren secara diam-diam (Maharani \& Arifin, 2016).

Boarding school diartikan sebagai sekolah yang menyediakan asrama untuk tempat tinggal sekaligus tempat mendidik peserta didiknya selama kurun waktu tertentu. Sekolah yang memiliki manajemen sekolah berasrama biasanya mewajibkan kepada peserta didiknya untuk tinggal dan dididik di asrama sesuai dengan waktu yang ditentukan (Hendriyenti, 2014).

Menurut Cookson and Persell (2008) Boarding School adalah bentuk pendidikan intensif, tempat siswa tinggal sekolah, dan kunjungi keluarga mereka hanya untuk akhir pekan dan liburan (Behaghel, 2017). Tempat tinggal peserta didik yang jauh dari rumah dipadukan dalam Boarding School dan mereka disana diajarkan agama serta pelajaran umum lainnya.

Selanjutnya Maksudin berpendapat Boarding school itu lembaga pendidikan di mana peserta didik tidak hanya belajar, tetapi mereka bertempat tinggal dan hidup di lembaga tersebut. Boarding school mengkombinasikan tempat tinggal peserta didiknya di institusi sekolah yang jauh dari rumah dan keluarga mereka dengan diajarkan agama serta pembelajaran beberapa mata pelajaran” (Maksudin, 2012). Istilah Boarding School berarti sekolah dasar atau menengah dengan asrama. Boarding School adalah sekolah di mana beberapa atau semua siswa belajar dan hidup selama masa studi bersama teman sekolah mereka dan mungkin juga para guru atau administrator (Hombersley, 2007).

Sekolah berasrama atau boarding school memadukan tempat tinggal para peserta didiknya di lembaga sekolah dari rumah dan keluarga mereka untuk diajarkan ilmu agama serta pembelajaran pengetahuan yang lain di tempat yang sama yaitu sekolah dan asrama. Pendidikan dengan sistem boarding school 
diharapkan dapat memberikan pengaruh yang positif terhadap karakter peserta didik karena di dalam asrama peserta didik tidak hanya mendapatkan ilmu pengetahuan tetapi juga mendapatkan ilmu keagamaan.

Sistem dari pendidikan boarding school menuntut para peserta didiknya tinggal dalam suatu asrama dan menetap disana selama waktu yang telah ditentukan. Sistem pendidikan seperti ini dapat memberikan pengawasan terhadap peserta didik dalam melakukan aktifitasnya agar menjadi kreatif dan produktif dengan adanya pengawasan selama 24 jam setiap hari karena mereka tinggal di asrama. Dengan demikian, sekolah asrama adalah sekolah yang semua siswanya tinggal di asrama yang dikelola secara terintegrasi dengan sekolah tersebut.

\subsection{Faktor pendukung berkembanganya Boarding School}

Di Indonesia boarding school lebih dikenal dengan istilah pondok pesantren modern, kehadirannya mewarnai dunia pendidikan sebagai lembaga yang bersamasama memiliki tujuan mencerdaskan kehidupan bangsa Indonesia yang bermoral dan berakhlak. Boarding school dalam perkembangannya sama seperti sekolahsekolah pada umumnya yang selalu berusaha mengikuti perkembangan zaman, menghadirkan inovasi- inovasi baru baik dari kurikulum, management, sarana dan prasarana. Boarding School sendiri merupakan salah satu inovasi dunia pendidikan yang memiliki karakter berbeda dengan sekolah umum, bedanya di dalam boarding school terdapat asrama untuk para peserta didik di sekolah tersebut (Hamdi, 2016).

Keberadaan boarding school dilarbelakangi oleh berbagai macam faktor. Di Indonesia pendidikan berasrama dianggap lebih mampu menyediakan pendidikan berkualitas yang komprehensif. Sekolah berasrama yang muncul di Indonesia umumnya berbasis agama namun berbeda dengan pola pendidikan pesantren (Faridah, 2018).

Menurut Khamdiyah (2013:3) dalam Anisa Rizkiani munculnya boarding school di Indonesia dilatarbelakangi keadaan pendidikan Indonesia yang selama ini dipandang belum memenuhi harapan yang ideal. Boarding school yang pola pendidikannya menyeluruh lebih memungkinkan untuk menciptakan lingkungan pendidikan yang ideal dan melahirkan orang-orang yang akan dapat membawa gerbong dan motor pergerakan kehidupan sosial, politik, ekonomi, dan agama (Rizkiani, 2012). 
Keberadaan Boarding School adalah suatu konsekuennsi logis dari perubahan lingkungan sosial dan keadaan ekonomi serta cara pandang religiusitas masyarakat. Mereka menganggap bahwa sekolah berasrama dianggap lebih baik dibanding non-berasrama. Sekolah non-berasrama dianggap tidak bisa menghasilkan lulusan yang mampu bersaing dengan peserta didik lain secara nasional dan global.

Boarding school menjadi salah satu alternatif bagi masyarakat yang menginginkan pendidikan yang menyeluruh dan menyatu, tidak hanya fokus pada sistem pembelajaran di sekolah saja, tetapi juga melatih anak untuk hidup mandiri yang dibarengi dengan keterampilan sosial yang baik. Kehidupan keasramaan dianggap sebagai salah satu alternatif untuk melatih karakter anak agar menjadi lebih mandiri, disiplin, dan melatih kepekaan anak terhadap perbedaan-perbedaan yang ada diluar dirinya (Faridah, 2018).

\subsection{Karakteristik Boarding School}

Sistem Boarding School merupakan salah satu karakteristik dasar sistem pendidikan pesantren, yang dikenal sebagai sistem santri mukim (Ridwan Nasir, 2005). Sistem pendidikan ini menggunakan sistem menginap bagi siswa sebagaimana santri di pesantren. Sistem sekolah asrama merupakan sistem yang menggabungkan fungsi keluarga di mana orang tua menanamkan nilai kepada anakanak mereka sementara sekolah lebih menekankan pada intelektual, dan fungsi masyarakat di mana anak-anak biasanya melakukan eksplorasi dan stabilisasi nilainilai (Rohman, 2014).

Karakteristik dari sistem pendidikan boarding school, diantaranya adalah: 1) dari segi sosial, sistem Boarding School yang mewajibkan peserta didik tinggal di asrama lingkungan sosial yang heterogen. Di lingkungan sekolah dan asrama yang relatif homogen yakni teman sebaya dan para guru pembimbing. Homogen dalam tujuan yakni menuntut ilmu sebagai sarana mengejar cita-cita. 2) Dari segi ekonomi, Boarding School memberikan layanan yang paripurna sehingga menuntut biaya yang cukup tinggi. Peserta didik akan benar-benar terlayani dengan baik melalui berbagai layanan dan fasilitas. 3) Dari segi semangat religiusitas, Boarding School menjanjikan pendidikan yang seimbang antara kebutuhan jasmani dan ruhani, intelektual dan spiritual (Pertiwi, 2017; Yakin, 2016). 


\section{Metode Penelitian}

Metode penelitian pada bab ini berisi tentang, pendekatan jenis penelitian, lokasi dan waktu penelitian, jenis dan sumber data, teknik pengecekkan keabsahan data, dan tahap-tahap penelitian.

\subsection{Pendekatan Penelitian dan Jenis Penelitian}

Penelitian ini menggunakan menggunakan pendekatan kualitatif dengan jenis deskriptif, yang mendeskripsikan fungsi manajemen kurikulum di SMP Aisyiyah Boarding School Malang dalam bentuk informasi verbal atau memaparkannya dalam bentuk kata-kata atau kalimat.

\subsection{Lokasi Penelitian dan Waktu Penelitian}

SMP ABSM yang beralamatkan di Jl. Argomoyo No. 35, Kelurahan Lawang, Kecamatan Lawang, Kabupaten Malang, Jawa Timur-Indonesia adalah sekolah dibawah naungan Pimpinan Daerah 'Aisyiyah (PDA) Kabupaten Malang.

Di awal berdiri, satuan pendidikan yang resmi adalah berupa Madrasah Tsanawiyah (MTs) namun setelah berjalan kira-kira satu tahunan berubah menjadi satuan pendidikan Sekolah Menengah Pertama (SMP). Sampai saat ini (2019) ABSM sudah berumur 7 Tahun. Tepat di umur ke 4, ABSM mengembangkan satuan pendidikan formal dengan mendirikan SMA Aisyiyah Boarding School Malang. Jadi sampai saat ini ABSM menyelenggarakan satuan pendidikan pada jenjangn SMP dan SMA.

Sejarah didirikannya sekolah menengah pertama 'Aisyiyah Boarding School Malang dikarenakan kekhawatiran akan kualitas dan kuantitas akan penerus kader putri 'Aisyiyah di lembaga Muhammadiyah yang mempunyai kecerdasan, berakhlaq mulia dan berilmu serta berwawasan dunia akhirat agar mampu menjadi pemimin yang baik dan bijak dimasa depan.

Visi dari SMP ABSM adalah mewujudkan lembaga kader putri Islam yang memiliki keunggulan dan berkualitas bersumber pada al-qr'an dan as-sunah. Adapun Misi meliputi : 1) menjadi lembaga pendidikan Islam berbasis pondok; 2) menyelenggarakan dan melaksanakan serta mendidik kader yang kompeten, cerdas, bertanggungjawab, dan berahlak mulia; 3) melaksanakan dan mengembangkan dalam pembiasaan diri pengamalan ajaran, sikap dan amaliah Islam; 4) memajukan dan mengembangkan pendidikan bahasa Arab dan bahasa Inggris sebagai media 
komunikasi untuk pendalaman agama dan teknologi; 5) menghasilkan dan mewujudkan lulusan yang kompeten dan berjiwa pemimpin.

Waktu penelitian dilaksanakan pada bulan Oktober sampai bulan Desember 2019

\subsection{Data Dan Sumber Data}

Data penelitian ini diperoleh dari hasil dokumentasi, wawancara, dan observasi. Penelitian ini menggunakan dua jenis data, yakni data primer dan data sekunder. Data primer yaitu data yang peneliti dapatkan secara langsung melalui observasi dan wawancara yang berkaitan dengan fungsi manajemen kurikulum di SMP ABSM. Kata-kata atau ucapan lisan dan perilaku manusia merupakan data utama dalam penelitian. Data sekunder adalah informasi yang diperoleh yang telah dikelola oleh pihak lain seperti segala macam dokumen yang ada di lembaga sekolah yang relevan dengan penelitian misalnya dokumen kurikulum, laporan kegiatan, rencana sekolah dan lain-lain (Sugiyono, 2010).

\subsection{Teknik Pengumpulan Data}

Untuk mendapatkan data yang dibutuhkan dalam penelitian kualitatif ini, peneliti melakukan teknik pengumpulan data di SMP Aisyiyah Boarding School Malang (ABSM) melalui dokumentasi, observasi, dan wawancara.Hasil yang ingin diperoleh adalah berupa dekripsi data tentang fungsi manajamen kurikulum yang mencakup perencanaan, pengorganisasian, pelaksanaan dan evaluasi.

Teknik dokumentasi dilakuakn dengan melihat dokumen kurikulum yang ada di SMP ABSM yaitu dokumen kurikulum KTSP, dokumen Kurikulum K13 dan dokumen Kurikulum Muhammadiyah. Selain melihat acuan kurikulum dalam program boarding school, penliti juga memproleh informasi tentang, profil sekolah visi, msi sekolah, data sarana dan prasarana, jumlah siswa dan jumlah guru.

Teknik wawancara dilakukan dengan Guru, kepala sekolah, pembina asrama dan peserta didik di SMP ABSM. Dibutuhkannya wawancara ini untuk memperoleh informasi tentang fungsi manajemen kurikulum yang ada di SMP ABSM.

Teknik observasi dilakukan peneliti untuk mengamati kegiatan sehari-hari yang dilakukan oleh guru, peserta didik dan unsur dalam sekolah lainnya yang berkaitan dengan fungsi manajemen kurikulum. 


\subsection{Teknik Analisa Data}

Penelitian ini menggunakan analisis data model Miles and Hubermen. (Sugiyono, 2016) mengungkapkan bahwa aktifitas dalam analisis data kualitatif dilakukan secara interaktif dan berlangsung secara terus menerus sampai tuntas sehingga datanya sudah jenuh.Aanalisis data yang dilakukan adalah reduksi data, penyajian data dan verifikasi data.

Reduksi data dilakukan dengan merangkum informasi terkait tentang implementasi manajemen kurikulum Boarding School di SMP ABSM, dengan merangkum informasi yang terkait dengan fungsi manajemen kurikulum. Perencanaan, pengorganisasian, pelaksanaan dan evaluasi kurikulum. Penyajian data dalm penelitian ini dilakukan dalam bentuk deskripsi. Kesimpulan atau verifikasi yang diambil dapat diubah pada waktunya sesuai dengan temuan di lapangan sampai pada kesimpulan akhir (berakhirnya penelitian).

\subsection{Uji Keabsahan Data}

Pengujian keabsahan data pada penelitian kualitatif menggunakan teknik trianggulasi. Triangulasi dalam pengujian kebenaran adalah sebagai pengecekan data dari berbagai sumber dengan berbagai cara dan waktu. Terdapat triangulasi sumber, triangulasi teknik pengumpulan data, dan waktu. Triangulasi merupakan pemeriksaan keabsahan data yang memanfaatkan sesuatu yang lain.

Teknik triangulasi sumber, peneliti mencoba mencocokan atau membandingkan hasil wawancara yang diperoleh dari masing-masig sumber atau responden sebagai pembanding dalam mengecek kebenaran informasi yang peneliti dapatkan.

\subsection{Tahap-tahap Penelitian}

Secara umum tahap penelitian ini terdiri dari tahap pralapangan, tahap pekerjaan lapangan, dan tahap analisis data. Pada tahap persiapan peneliti melakukan penelitian tempat, mengurus surat izin, menjajaki dan menilai lapangan, menentukan informasi dan menyiapkan perlengkapan penelitian.

Tahap persiapakan dilaksanakan pada bulan Oktober 2019. Tahap persiapan pada penelitia ini peneliti mempelajari situasi, kondisi, kebiasaan yang khas di SMP Aisyiyah Boarding School Malang sebagai pertimbangan dan penguatan untuk penelitian. Perlengkapan penelitian yang harus dipersiapkan yaitu pedoman 
wawancara, observasi, rekam, buku catatan dan jadwal penelitian. Sedangkan pada tahap pekerjaan lapangan, peneliti pengumpulkan data dengan observasi, wawancara, dan dokumentasi.

\section{Hasil Penelitian}

\subsection{Perencanaan Kurikulum}

Setelah peneliti melakukan penelitian dengan mengambil, mengolah dan menganalisis data ditemukan beberapa hal terkait dengan implementasi manajemen kurikulum di SMP ABSM adalah sebagai berikut :

SMP ini nenerapkan kurikulum KTSP dan Kurikulum K13. Mulai tahun pelajaran 2018-2019 menerapkan kurikulum K13 untuk kelas VII dan kelas VIII. Dalam pelaksanaannya kurikulum di SMP ABSM dikembangkan secara efektif dalam rangka meningkatkan kompetensi dan potensi yang akan dicapai dalam setiap mata pelajaran. Selain kurikulum nasioanal (K13 dan KTSP) di SMP ABSM terdapat kurikulum pesantren, dan kurikulum khas Muhammadiyah. Hasil pengamatan penulis seperti yang disampaikan oleh subyek penelitian yang menerangkan bahwa :

“ Dalam penerapan kurikulum di SMP ABSM mengintegrasikan kurikulum nasional, kurikulum pesantren, dan kurikulum Muhammadiyah yang dilakukan secara penuh demi menghasilkan lulusan yang berstandar nasioanal, berwawasan aqidah, ahlaq, dan fiqih sesuai tuntutan Qur'an dan Sunnah “. (R2, $11 / 10 / 2019)$

Pengintegrasian kurikulum sekolah berasrama antara kurikulum nasional, kurikulum pesantren dan kurikulum khas sekolah haruslah saling berkesinambungan untuk mewujudkan tujuan yang ingin dicapai. Sekolah ini tujuannya adalah untuk menjadikan generasi kader muda putri Muhammadiyah yang mempunyai kecerdasan, berakhlaq mulia dan berilmu serta berwawasan dunia akhirat agar mampu menjadi pemimin yang baik dan bijak dimasa yang akan datang.

SMP Aisyiyah Boarding School Malang (ABSM) merupakan sekolah putri yang berbasis pondok pesantren modern, yang menerapkan kurikulum lebih dari satu yaitu kurikulum kemendikbud, kurikulum diniyah/pesantren serta kurikulum Muhammadiyah. Untuk pelajaran umum kurikulumnya dari kemendikbud sedangkan untuk pelajaran pesantren mereka dapat dari perpaduan antara kurikulum 
Muhamadiyah dan kurikulum khas sekolah itu sendiri. Dari pengamatan peneliti diperoleh informasi sebagai berikut

“Kurikulum yang direncanakan di SMP ABSM adalah perpaduan antara kurikulum formal dan kurikulum pesantren dan kurikulum Muhammadiyah yaitu ISMUBA (Al-Islam, Kemuhammadiyahan dan Bahasa Arab) dengan pengembangan potensi diri yang bersifat integratif, komprehensif dan mandiri “. (R2/11/10/2019)

SMP Aisyiyah disini dalam manajemen kurikulumnya menyeimbangkan perpaduan antara kurikulum nasional dengan kurikulum pesantren secara efektif. Model pembelajarannnya pun harus memperhatikan kurikulum yang berlaku sesuai dengan potensi yang ada di sekolah. Hal ini diperkuat dengan penyataan subyek penelitian berikut ini.

" Model pembelajaran di SMP ABSM disesuaikan dengan kerakteristik/kemampuan guru yang disesuaikan dengan kurikulum yang berlaku dengan memanfaatkan segala potensi yang ada di lingkungan sekolah (kelas, luar kelas, dan fasilitas pendukung pembelajaran) “. (R2/11/10/2019)

Sekolah asrama atau boarding school kegiatan yang dilakukan oleh peserta didiknya sangatlah padat oleh karena itu manajemen kurikulum SMP ABSM haruslah memperhatikan fungsi dari manajemen. Fungsi manajemen itu sendiri seperti, perencanaan, pengorganisasian, pelaksanaan dan evaluasi. Karena keberhasilan sekolah dalam menjalankan segala aktifitas salah/satunya ditentukan oleh faktor manajemen yang diselenggarakan oleh sekolah itu sendiri. Seperti yang dinyatakan subyek penelitian berikut ini.

“ Dalam hal iperencanaan kurikulum kegiatan utama yang kami lakukan adalah menggunakan manajemen yang efektif seperti penentuan yang berupa strategi pelaksanaan kurikulum, disini pelaksana yang terlibat adalah kepala sekolah, guru dan pengawas sekolah “. (R2/10/11/2019)

Pelaksanaan kurikulum boarding school merupakan suatu gerakan aksi yang dilakukan oleh sekolah dalam program kurikulum dapat berjalan dengan baik sesuai perencanaan yang terkait dengan keseluruhan fungsi manajemen. Pelaksanaan program kurikulum yang sudah matang tidak terlepas adanya faktor penghambat atau kendala-kendala teknis terutama yang berkaitan dengan pelaksana kurikulum. 
Sistem boarding school ini dimana peserta didik bukan hanya pendidikan formal dari pemerintah yang diterima, namun pendidikan agama juga mereka dapatkan dari sistem pendidikan di pesantern.

Sistem atau pola pendidkan di sekolah ini merapkan salah satu metode internalisasi pendidikan Islam melalui pembiasaan. Tujuan dari pendidikan dengan sistem boarding school adalah untuk mewujudkan penerus kader putri 'Aisyiyah di lembaga Muhammadiyah yang mempunyai kecerdasan, berakhlaq mulia dan berilmu serta berwawasan dunia akhirat agar mampu menjadi pemimin yang baik dan bijak dimasa depan. Sehingga dalam pelaksanaan pendidikan di SMP ABSM bukan hanya pendidikan akademik, tetapi juga mendidik karakter dan keagamaan peserta didik agar menjadi kader-kader yang berilmu dan berakhlak mulia.

Penerapan pola kurikulum boarding school berkaitan dari perencanaan sekolah untuk mencapai visi, misi dan tujuan yang diinginkan. Sesuai atau tidaknya apa yang telah dirumuskan dari awal merupakan bagian dari perencanaan tentang visi, misi dan tujuan.

Dari visi, misi dan tujuan inilah bagaimana sistem boarding school sudah sesuai denga apa yang telah dirumuskan dari awal. Hal ini diperkuat dengan subyek penelitian dibawah ini.

"Kurikulum di SMP ABSM direncanakan bersama dengan SMA yang melibatkan struktural dikdasmen, sekolah guru dan stekeholder yang diawali dengan penentuan visi, misi, dan tujuan yang disesuaikan dengan 3 kurikulum yaitu kurikulum nasional, kurikulum pesantren dan kurikulum khas Muhammadiyah “. (R1/10/11/2019)

“Visi SMP ABSM merupakan cita-cita didirikannya sekolah ini. Visi dan misi adalah sebagai dasar pembuatan program-program dalam menjalakan kegiatan peserta didik untuk membentuk lulusan yang diharapkan ". (R2/10/11/2019)

SMP ABSM yang berbasis pesantren membutuhkan perencaanan dan strategi dalam pelaksanaan kurikulum. Perencanaan kurikulum yang terkait dengan hal ini merupakan bagian yang penting pada pelaksanaan pengimplementasian kurikulum. Perencanaan kurikulum di SMP ABSM meliputi segala aspek yang berkaitan dengan kurikulum sekolah. 
"Perencanaan yang dilakukan di SMP ABSM sebelum memasuki tahun ajaran baru adalah menyiapkan guru untuk mengikuti pelatihan atau workshop dalam penyusunan rencana dan strategi pembelajaran yang sesuai dengan kurikulum yang ditetapkan “. (R1/10/11/2019)

Tujuan dari perencanaan kurikulum merupakan proses atau tahapan dalam penyusunan materiyang akan diajarkan, penggunaan media, strategi dan metode pembelajaran serta penilaian dalam alokasi waktu yang direncanakan pada kurun waktu tertentu dalam bentuk silabus dan rencana pelaksanaan pembelajaran atau RPP.

Proses perencanaan kurikulum di SMP Aisyiyah Boarding School Malang membagi ke dalam dua tingkatan yaitu perencanaan kurikulum tingkat sekolah dan perencanaan kurikulum tingkat kelas.

Perencanaan kurikulum di sekolah yang bertugas menyusun konsep dan, merencanakan dan membuat kalender akademik sekolah, jadwal pelajaran serta kegiatan atau program sekolah dalam satu tahun adalah kepala sekolah dibantu oleh tim kurikulum yang diketuai oleh wakil kepala bidang kurikulum (waka kurikulum).

" Kurikulum sekolah disusun bersama-sama kepala sekolah dengan tim kurikulum yang diketuai oleh waka kurikulum dan guru yang ditelah ditunjuk ". (R3/12/11/2019)

Sedangkan perencanaan kurikulum di kelas wajib dipersiapkan dan dibuat oleh setiap guru mata pelajaran yang berupa program tahunan, program semester, silabus dan RPP sesuai dengan kurikulum yang ditetapkan yaitu kurikulum KTSP untuk kelas IX dan kurikulum K13 untuk kelas VII dan VIII. Sehingga guru mempunyai peran penting dalam proses perencanaan kurikulum.

Kurikulum muatan keagamaan atau kurikulum madin disusun dan dibuat sendiri oleh pihak pesantren yang disesuaikan dengan aturan yanng berlaku. Perencanaan dalam kegiatan asrama diatur oleh bidang keagamaan (madin) dengan melakukan koordinasi dengan pihak sekolah atau yayasan maupun pengelola asrama dalam rapat awal tahun pelajaran. 


\subsection{Pengorganisasian Kurikulum}

Pengorganisasian kurikulum yang dilaksanakan SMP ini mencakup bagianbagian kegiatan atau program yang diperlukan untuk mencapai tujuan, dan membagi tugas sesuai dengan tugas kerjanya masing-masing. Pembagian tugas yang dilakukan oleh kepala sekolah sebagai manajer sangatlah diperlukan agar tujuan dapat tercapai. Kepala sekolah mempunyai wewenang dalam organisasi yang dipimpinnya. Manajemen yang dikembangkan di SMP ABSM ini pertama yang dilakukan adalah menentukan struktur organisasi sekolah yang meliputi pelindung, penanggunng jawab, kepala sekolah, wakil kepala bidang kurikulum, wakil kepala bidang kesiswaan, tata usaha, bendahara dan wali kelas disetiap jenjangnya.

"struktur organisasi di sekolah ini tidak berbeda jauh denga sekolahsekolah lain yang ada, disini strukturnya ada mulai dari pelindung, penanggung jawab sampai pada wali kelas “. (R1/12/11/2019)

Selain penggorganiasian yang dilakukan dengan struktur dan pembagian yang jelas, SMP ABSM juga menentukani langkah-langkah dalam proses atau prosedur pembelajaran yaitu dengan menetapkan jumlah jam pelajaran dan jenis mata pelajaran pada masing-masing jam mengajar guru.

Dalam pengorganisasian kurikulum, terdapat dua hal yang harus diperhatikan yaitu kurikulum sebagai aturan dalam bahan pelajaran dan kurikulum sebagai pengelolaan. Perpaduan antara keduannya kedalam semua program kurikulum adalah agar bisa diimplementasikan kedalam kegiatan belajar mengajar dengan optimal.

" Dalam hal pengorganisasian kurikulum di SMP ABSM menggunakan model pengintegrasian kurikulum. Pengaturan bahan pelajaran dan pengelolaan harus tersinkronisasi terhadap semua program kurikulum. Adapun perpaduan yang dimakasudkan di SMP ABSM adalah mingintegrasikan antara ilmu umum (sains) dan ilmu agama “. (R2/12/11/2019)

Sekolah ini menentukan program-program pembelajaran dan kegiatankegiatan yang sifatnya dapat menunjang tercapainya tujuan pembelajaran. Programprogram untuk menunjang kegiatan tersebut diantaranya adalah kajian kitab, penerapan mufrodat, tahfidz, muhadharah, dan kelompok belajar. Dan kemudian menentukan waktu atau jadwal pelaksanaan kegiatan. 


\subsection{Pelaksanaan Kurikulum}

Pelaksanaan kurikulum merupakan hal yang palinng utama dalam implementasi kurikulum. Yang dilaksanakan adalah apa yang telah direncanakan. Perencanaan kurikulum lebih berhubungan dengan aspek yang abstrak sedangkan proses pelaksanaan kurikulum berhubungan langsung dengan kurikulum.

Kurikukulum nasional yang diterapkan di SMP ABSM menggunakan kurikulun tingkat satuan pendidikan dan kurikulum dua ribu tiga belas. Selain kurikulum nasional juga ada kurikulum khas pesantren yaitu mengkaji kitab-kitab dan kurikulum Muhammadiyah.

"Sekolah disini adalah berbasis pondok pesentren, selain terdapat mata pelajaran pada umumnya juga terdapat mata pelajaran keislaman contohnya Bahasa Arab, Fiqih, Al- Islam, mengkaji kitab dan lain-lain “. (R3/12/11/2019)

Pelaksanaan kurikulum merupakan upaya kepala sekolah dalam memimpin untuk memberikan pengarahan atau dorongan kepada pelaksana kegiatan yaitu guru maupun staf agar mencapai tujuan dari visi dan misi yang telah ditetapkan.

" Kepala sekolah selalu memberi pengarahan dan solusi kepada kami guru jika terdapat masalah dalam praktik pembelajaran, selain itu beliau tidak segan menegur atau menasehati jika kami menyalahi kesepakatan awal dalam pembelajaran ". (R3/12/11/2019)

Guru sebagai penentu dalam pelaksanaan kurikulum di kelas haruslah mempunyai kompetensi dan keahlian yang unggul terhadap keilmuan yang disampaikan kepada peserta didiknya. Tahap pertama dalam pelaksanaan guru merencanakan alur pembelajaran yang mencakup kegiatan pendahuluan, kegiatan inti dan kegiatan penutup. Sedangkan kepala sekolah memiliki wewenang dalam melakukan pengawasan terhadap proses pembelajaran.

Peran guru sangat sentral dalam pelaksanaan kurikulum baigaimana guru dapat mengelola kelas dengan baik dan tepat. Guru diberikan kebebasan dalam mengelola kelas tergantung dengan apa yang akan disampaikan yang terkait dengan materi dan metode yang digunakan.

" Pada waktu masuk kelas, sebelum memulai pembelajaran kami selalu meyusun RPP terlebih dahulu dengan memperhatikan keadaan peserta didik dengan skenario pembelajaran yang meliputi kegiatan pendahuluan, kegiatan inti dan kegiatan penutup. Strategi dan model pembelajaran yang kami lakukan kami sesuiakan dengan metode pembelajaran yang dianjurkan seperti discovery learning dan lainnya “. (R5/12/11/2019) 
Pelaksanaan pembelajaran yang dilakukan di asrama, dalam materinya ialah mempelajari dan mengkaji kitab-kitab serta pembiasaan yang dilakukan terkait hubungannya dengan materi kebiasaan sehari-hari peserta didik. Pembelajaran yang dilakukan adalah dengan menanamkan pembiasan sehari-hari peserta didik atau santri. Bagaimana melakukan kegiatannya dalam kehidup sehari-hari di asrama maupun di sekolah untuk beradaptasi, menyelesaikan masalah, praktik ibadah terutama sholat.

\subsubsection{Evaluasi Kurikulum}

SMP ABSM dalam melakukan evaluasi dilakukan tiap hari, setiap bulan, setiap semesteran dan pada akhir tahun pelajaran. Untuk mengetahui hasil dari pelaksanaan kurikulum dalam satu tahun pelajaran adalah bagian dari tujuan evaluasi. Langkah dalam evaluasi ini menyangkut semua program yang telah direncanakan untuk dilaksanakan. Ketika ada program yang dianggap kurang memadai maka dilakukan perbaikan pada kinerja berikutnya.

" Evaluasi yang dilaksanakan di sekolah ini terkait program sekolah secara keseluruhan dan dilaksanakan setiap sebulan sekali sedangkan evaluasi yang terkait dengan pelaksanaan kurikulum dilakukan setiap hari karena di dalam RPP guru terdapat refleksi untuk evaluasi “. (R1/12/11/2019).

Selain evaluasi program pembelajaran dan kurikulum, praktek pembelajaran juga terdapat evaluasinya. Eavaluasi hasil belajar dilakukan oleh guru dengan memberikan penilaian yang bertujuan untuk memantau dan mengevaluasi proses, kemajuan belajar peserta didik. Sehingga guru dapat mengetahui perkembangan kemajuan dan hasil belajar, sehingga mampu memberikan umpan balik pada peserta didiknya.

“ setiap bulan kita melakukan evaluasi kepada peserta didik dalam bentuk ulangan harian, sedangkan untuk penilaian aspek psikomotorik dan afektif kita lakukan penilain setiap hari ketika waktu pembelajaran berlangsung “. (R5/12/11/2019)

Evaluasi yang dilakukan bukan hanya terhadap peserta didik akan tetapi guru juga dilakukan pengevaluasian terhadap kinerjanya. Proses implementasi kurikulum yang terkait dengan kinerja guru, untuk mendukung proses pelaksanaan kurikulum guru harus menyusun dan mempersiapkan segala sesuatu yang dibutuhkan. 
“ Kepala sekolah melakukan evaluasi atau pengawasan terhadap kinerja guru setiap hari, terkait dengan supervisi dilaksanakan sekali dalam semester. Sementara evaluasi secara keseluruhan dilaksanakan setiap akhir tahun pelajaran “. (R1/15/11/2019)

Evaluasi kurikulum yang dilakukan SMP ABSM pada setiap akhir tahun pelajaran digunakan untuk mengevaluasi keseluruahan dari pelaksanaan kurikulum yang bertujuan mengatasi permaslahan yang timbul pada implementasi kurikulum apakah kurikulum yang dilakukan telah berjalan sesui dengan perencanaan yang ditentukan.

\section{Pembahasan}

Implementasi manajemen kurikulum di SMP ABSM yang meliputi analisis perencanaan, analisis pengorganisasian, analisis pelaksanaan dan analisis evaluasi menggunakan analasis deskriptif.

SMP ABSM nenerapkan kurikulum KTSP dan Kurikulum K13. Mulai tahun pelajaran 2018-2019 menerapkan kurikulum K13 untuk kelas VII dan kelas VIII. Dalam pelaksanaannya kurikulum di SMP ABSM dikembangkan secara efektif dalam rangka meningkatkan kompetensi dan potensi yang akan dicapai dalam setiap mata pelajaran. Selain kurikulum nasioanal (K13 dan KTSP) di SMP ABSM terdapat kurikulum pesantren, dan kurikulum khas Muhammadiyah.

Perbedaan hasil penelitian ini dengan penelitian-penelitian tedahulu tentang manajemen kurikulum adalah perbedaannya terletak pada kurikulum itu sendiri, yaitu di SMP ABSM selain kurikulum nasional dan pesantren terdapat kurikulum yang khas yaitu kurikulum Muhammadiyah. Kurikulum Muhammadiyah di SMP ABSM bermuatan Al-islam, Kemuhammadiyahan dan Bahasa Arab (ISMUBA) yang disusun oleh Yayasan Pendidikan Muhammadiyah.

Sistem atau pola pendidkan di SMP ABSM merupakan salah satu metode internalisasi pendidikan Islam melalui pembiasaan. Tujuan dari pendidikan dengan sistem boarding school adalah untuk menjadikan kader-kader putri Muhammadiyah sebagai mubaliqghot yang mempunyai kecerdasan tinggi, berakhlaq mulia, berilmu dan berkarakter, mempunyai wawasan dunia akhirat dengan baik serta mampu menjadi pemimpin bijak yang baik di masa depan. Sehingga dalam pelaksanaan 
pendidikan di SMP ABSM mendidik secara formal dalam bidang akademik dan mendidik karakter dan spiritual peserta didik agar menjadi kader-kader yang berilmu dan berakhlak mulia.

Penerapan pada sistem boarding school dibutuhkan perencanaan pendidikan yang baik agar visi, misi, dan tujuan yang diingikan dapat tercapai. (Maksudin, 2013). Menurut Rusman perencanaan kurikulum adalah langkah awal membangun kurikulum ketika pekerja kurikulum membuat keputusan dan mengambil tindakan untuk menghasilkan perencanaan yang akan digunakan oleh guru dan peserta didik (Rusman, 2018). Kurikulum yang berisikan perencanaan bertujuan untuk membina peserta didik terhadap perubahan tingkah laku yang diinginkan.

Dari paparan hasil penelitian, terlihat jelas bahwa manajemen yang diterapkan dalam pelaksanaan boarding school berangkat dari perencanaan yang dilakukan oleh seluruh dewan guru pada awal tahun atau awal semester dengan memperhatikan pada visi, misi, dan tujuan sekolah.

Tujuan dari perencanaan kurikulum merupakan proses atau tahapan dalam penyusunan materi yang akan diajarkan, penggunaan media, strategi dan metode pembelajaran serta penilaian terhadap alokasi waktu yang direncanakan pada kurun waktu tertentu dalam bentuk silabus dan rencana pelaksanaan pembelajaran atau RPP.

Proses perencanaan kurikulum di SMP Aisyiyah Boarding School Malang membagi ke dalam dua tingkatan yaitu perencanaan kurikulum tingkat sekolah dan perencanaan kurikulum tingkat kelas.

Perencanaan kurikulum pada tingkatan sekolah yang bertugas menyusun konsep dan, merencanakan dan membuat kalender akademik sekolah, jadwal pelajaran serta kegiatan atau program sekolah dalam satu tahun adalah kepala sekolah dibantu oleh tim kurikulum yang diketuai oleh wakil kepala bidang kurikulum.

Sedangkan perencanaan kurikulum pada tingkatan kelas wajib dipersiapkan dan dibuat oleh setiap guru mata pelajaran yang berupa program tahunan, program semester, silabus dan RPP sesuai dengan kurikulum yang ditetapkan yaitu kurikulum KTSP untuk kelas IX dan kurikulum K13 untuk kelas VII dan VIII. Sehingga guru mempunyai peran penting dalam proses perencanaan kurikulum. Hal 
ini sejalan dengan yang diungkapkan Hamalik bahwa betapapun bagus dan indahnya kurikulum, keberhasilan kurikulum tersebut pada akhirnya bergantung pada masingmasing guru (Hamalik, 2013).

Kurikulum muatan keagamaan atau kurikulum madin disusun dan dibuat sendiri oleh pihak pesantren yang disesuaikan dengan aturan yanng berlaku. Perencanaan dalam kegiatan asrama diatur oleh bidang keagamaan (madin) dengan melakukan koordinasi dengan pihak sekolah atau yayasan maupun pengelola asrama dalam rapat awal tahun pelajaran.

Sementara itu dalam pengorganisasian kurikulum yang dilaksanakan SMP ABSM ini mencakup bagian-bagian kegiatan atau program yang diperlukan untuk mencapai tujuan, dan membagi tugas sesuai dengan tugas kerjanya masing-masing. Pembagian tugas yang dilakukan oleh kepala sekolah sebagai manajer sangatlah diperlukan agar tujuan dapat tercapai. Kepala sekolah mempunyai wewenang dalam organisasi yang dipimpinnya. Manajemen yang dikembangkan di SMP ABSM ini pertama yang dilakukan adalah menentukan struktur organisasi sekolah yang meliputi pelindung, penanggunng jawab, kepala sekolah, wakil kepala bidang kurikulum, wakil kepala bidang kesiswaan, tata usaha, bendahara dan wali kelas disetiap jenjangnya.

Menurut Sudjana, dalam Ali Khudrin pengorganisasian itu mengumpulkan dan membuat penyususnan semua sumber organisasi yang rencanakan dalam perencanan. Aktifitas dalam membentuk organisasi mencakup sumber daya manusia untuk menjalankan kegiatan atau program yang telah direncanakan untuk menggapai tujuan yang ditetapkan (Khudrin, 2008)

Selain penggorganiasian yang dilakukan dengan struktur dan pembagian yang jelas, SMP ABSM juga menentukan langkah-langkah dalam proses atau prosedur pembelajaran yaitu dengan menetapkan jumlah jam pelajaran dan jenis mata pelajaran pada masing-masing jam mengajar guru.

Dalam pengorganisasian kurikulum, terdapat dua hal yang harus diperhatikan yaitu kurikulum sebagai aturan dalam bahan pelajaran dan kurikulum sebagai pengelolaan. Perpaduan antara keduannya kedalam semua program kurikulum adalah agar bisa diimplementasikan kedalam kegiatan belajar mengajar dengan optimal. 
Hal yang paling utama dalam pelaksanaan kurikulum adalah dalam hal implementasi kurikulum. Yang dilaksanakan adalah apa yang telah direncanakan. Perencanaan kurikulum lebih berhubungan dengan aspek yang abstrak sedangkan proses pelaksanaan kurikulum berhubungan langsung dengan kurikulum.

Berdasarkan temuan pada penelitian ini, Guru sebagai penentu dalam pelaksanaan kurikulum di kelas haruslah mempunyai kompetensi dan keahlian yang unggul terhadap keilmuan yang disampaikan kepada peserta didiknya. Tahap pertama dalam pelaksanaan guru merencanakan alur pembelajaran yang mencakup kegiatan pendahuluan, kegiatan inti dan kegiatan penutup. Sedangkan kepala sekolah memiliki wewenang dalam melakukan pengawasan terhadap proses pembelajaran.

Menurut pendapat Rusman hal-hal yang harus diperhatikan dalam pelaksanaan kurikulum itu guru harus termotivasi bahwa apa yang dikerjakan bermanfaat dan tidak menjadi beban sehinnga guru peracaya dengan tugas pekerjaannya dan hubungan dengan antar teman tetap harmonis (Rusman, 2018). Jadi peran guru sangat sentral dalam pelaksanaan kurikulum baigaimana guru dapat mengelola kelas dengan baik dan tepat. Guru diberikan kebebasan dalam mengelola kelas tergantung dengan apa yang akan disampaikan yang terkait dengan materi dan metode yang digunakan.

SMP ABSM dalam melakukan evaluasi dilakukan tiap hari, setiap bulan, setiap semesteran dan pada akhir tahun pelajaran. Untuk mengetahui hasil dari pelaksanaan kurikulum dalam satu tahun pelajaran adalah bagian dari tujuan evaluasi. Langkah dalam evaluasi ini menyangkut semua program yang telah direncanakan untuk dilaksanakan. Ketika ada program yang dianggap kurang memadai maka dilakukan perbaikan pada kinerja berikutnya.

Evaluasi yang dilakukan bukan hanya terhadap peserta didik akan tetapi guru juga dilakukan pengevaluasian terhadap kinerjanya. Proses implementasi kurikulum yang terkait dengan kinerja guru, untuk mendukung proses pelaksanaan kurikulum guru harus menyusun dan mempersiapkan segala sesuatu yang dibutuhkan. Kepala sekolah melakukan pengawasan atau evaluasi terhadap kinerja guru setiap hari, terkait dengan supervisi dilaksanakan sekali dalam semester. Sementara evaluasi secara keseluruhan dilaksanakan setiap akhir tahun pelajaran. 
Pengevaluasian kurikulum yang dilaksanakan SMP ABSM pada setiap akhir tahun pelajaran digunakan untuk dapat mengevaluasi keseluruahan dari pelaksanaan kurikulum yang bertujuan mengatasi permaslahan yang timbul pada implementasi kurikulum apakah kurikulum yang dilakukan telah berjalan sesui dengan perencanaan yang ditentukan.

\section{Kesimpulan dan Saran}

\subsection{Simpulan}

Berdasarkan hasil penelitian implementasi manajemen kurikulum di SMP ABSM, dapat ditarik kesimpulan bahwa manajemen kurikulum yang dilaksanakan di SMP ‘Aisyiyah Boarding School Malang meliputi :

Kurikulum yang digunakan di SMP ABSM adalah kurikulum perpaduan antara kurikulum nasional, kurikulum pesantren dan kurikulum Muhammadiyah. Dalam perencanaannya kurikulum yanng dilaksanakan benar-benar direncanakan dengan matang oleh pihak yang terkait seperti kepala sekolah dan tim kurikulum.

Pengorganisasian yang dilakukan di SMP ABSM mencakup bagian-bagian kegiatan atau program yang diperlukan untuk mencapai tujuan, dan membagi tugas sesuai dengan tugas kerjanya masing-masing. Pembagian tugas yang dilakukan oleh kepala sekolah sebagai manajer sangatlah diperlukan agar tujuan dapat tercapai. Kepala sekolah mempunyai wewenang dalam organisasi yang dipimpinnya. Manajemen yang dikembangkan di SMP ABSM ini pertama yang dilakukan adalah menentukan struktur organisasi sekolah yang meliputi pelindung, penanggunng jawab, kepala sekolah, wakil kepala bidang kurikulum, wakil kepala bidang kesiswaan, tata usaha, bendahara dan wali kelas disetiap jenjangnya.

Guru menjadi kunci utama keberhasilan pelaksanaan kurikulum dalam mewujudkan konsep, prinsip dan aspek kurikulum. Peran guru sangat sentral dalam pelaksanaan kurikulum baigaimana guru dapat mengelola kelas dengan baik dan tepat. Guru diberikan kebebasan dalam mengelola kelas tergantung dengan apa yang akan disampaikan yang terkait dengan materi dan metode yang digunakan. Proses pembelajaran yang dilakukan dengan pembiasan sehari-hari peserta didik atau santri. Bagaimana mereka melakukan aktifitasnya dalam kehidupan sehari-hari di asrama 
dan sekolah untuk beradaptasi, menyelesaikan masalah, praktik ibadah terutama sholat.

Pengevaluasian di SMP ABSM dilaksanakan setiap akhir tahun pelajaran digunakan untuk mengevaluasi keseluruahan dari pelaksanaan kurikulum yang bertujuan mengatasi permaslahan yang timbul pada implementasi kurikulum apakah kurikulum yang dilakukan telah berjalan sesui dengan perencanaan yang ditentukan.

\subsection{Saran}

Dari hasil penelitian dan simpulan yang telah dikemukakan. Peneliti memberikan saran sebagai berikut: Kedepannyaa manajemen kurikulum di SMP ABSM dikelola dengan baik melalui berbagai kebijakan dan strategi perencanaan, pengorganisasian, pelaksanaan dan evaluasi yang efektif dan efisien. Sehingga apa yang menjadi cita-cita, visi, misi dan tujuan yang diharapkan dapt terwujud.

\section{RUJUKAN}

Arikunto, S. (2017). Manajemen Pendidikan (Revisi). Yogyakarta: Aditya Media.

Behaghel, L. (2017). Ready for boarding? The effects of a Boarding School for Disadvantaged students. Applied Economics, 9(1), 140-164. https://doi.org/10.1257/app.20150090

Dian, T. (2016). Manajemen Kurikulum di SMP Muhammadiyah Boarding School Prambanan Sleman Yogyakarta. Jurnal Hanata Widya, 5, 37-48.

Faridah. (2018). Sekolah berasrama di sulawesi selatan. Lentera Pendidikan, 20(2), $142-153$.

Fathurrochman, I. (2017). Implementasi Manajemen Kurikulum Dalam Upaya Meningkatkan Mutu Santri Pondok Pesantren Hidayatullah / Panti Asuhan Anak Soleh Curup Irwan Fathurrochman A . Pendahuluan Pesantren menurut pengertian dasarnya adalah tempat belajar para santri . Sebagai lemba. TADBIR : Jurnal Studi Manajemen Pendidikan, 1(01), 86-104.

Fikri, M., \& Ferdinan. (2013). Peranan Manajemen Boarding School Dalam Meningkatkan Prestasi Belajar Pendidikan Agama Islam. Jurnal Tarbawi, 2(1), $43-52$.

Hamalik, O. (2013). Dasar-dasar Pengembangan Kurikulum. Bandung: PT Remaja Rosdakarya. 
Hamdi, N. (2016). Perancangan Eco-Islamic Boarding School di Sukoraja. Http://Etd.Repository.Ugm.Ac.Id/, 1-9.

Hasan, M. (2016). Inovasi dan Modernisasi Pendidikan Pondok Pesantren. KARSA: Jurnal Sosial Dan Budaya Keislaman. https://doi.org/10.19105/karsa.v23i2.728

Hasibuan, M. (2015). Manajemen Dasar Pengertian dan Masalah. Jakarta: Bumi Aksara.

Hendriyenti. (2014). Pelaksanaan Program Boarding School Dalam Pembinaan Moral Siswa Di Sma Taruna Indonesia Palembang. Ta'dib, XIX(02), 203-226.

Hombersley, S. (2007). Boarding school. Engineer.

Khudrin, A. (2008). Implementasi manajemen kurikulum pada madrasah diniyah al-aziz pondok pesantren nurul buda ii kabupaten sleman d.i. yogyakarta. Nafisd, $X V(02)$, $15-28$.

Machali, D. K. dan I. (2012). Manajemen Pendidikan Konsep dan Prinsip Pengelolaan Pendidikan. Jogjakarta: Ar-Ruzz Media.

Maharani, D. I., \& Arifin, I. (2016). Manajemen pembelajaran pondok pesantren. Manajemen Dan Supervisi Pendidikan.

Maksudin. (2012). Sistem Boarding School (Transformasi dan Humanisme Religius). Jurnal Cakrawala Pendidikan, (1), 38-54. https://doi.org/10.21831/cp.v0i1.1465

Maksudin. (2013). Pedidikaan Islam Alternatif: Membangun karakter melalui sistem boarding school. Yogjakarta: UNY Press.

Paminto, J., Rosiana, T., \& Budisantoso, H. T. (2018). Indonesian Journal of Curriculum Implementasi Kurikulum 2013 di Sekolah Pesantren dengan Sistem Boarding School. Indonesian Journal Of Currikulum and Educational Technologi Studies, 6(1), 41-52. https://doi.org/http://dx.doi.org/10.15294/ijcets.v3i1.8675 Article

Pertiwi, D. A. (2017). Implementasi Program Pendidikan Asrama Dalam Meningkatkan Kecerdasan Spiritual Santriwati Di Asrama Bahasa Arab Hubbul Wathan Medan. At-Tazakki Jurnal Pendidikan Islam, 1, 101-121.

Priyanto, D. (2006). Inovasi Kurikulum Pesantren Pesantren. Ibda'.

R.Terry, G. dan L. W. R. (2010). Dasar-Dasar Manajenen. Jakarta : Bumi Aksara.

Ridwan Nasir. (2005). Mencari Tipologi Format Pendidikan Ideal Pondok Pesantren Ditengah Arus Perubahan. Yogyakarta : Pustaka Pelajar. 
Rizkiani, A. (2012). Pengaruh Sistem Boarding School Terhadap Pembentukan Karakter Peserta Didik ( Penelitian di Ma' Had Darul Arqam Muhammadiyah Daerah Garut ). Jurnal Pendidikan Universitas Garut, 06(01), 10-18. Retrieved from https://journal.uniga.ac.id

Rohman, A. (2014). Junior-Senior High School Based On Pesantren Boarding System. Jurnal Pendidikan Islam, 1 .

Rusman. (2018). Manajemen Kurikulum. PT Raja Grafindo Persada Jakarta.

Ruswanto. (2017). Pesantren dan Pembaharuan. Al-Tadzkiyyah: Jurnal Pendidikan Islam. https://doi.org/10.24042/ATJPI.V7I1.1496

Sista, T. R. (2017). Implementasi Manajemen Kurikulum Dalam Meningkatkan Mutu Pendidikan. EDUKAN Jurnal Pendidikan Islam, 01(01).

Siswiyo, D. (1996). Ilmu pendidikan dalam tantangan. Cakrawala Pendidikan, 15(1), $1-13$.

Sugiyono. (2010). Metode Penelitian Kuantitatif \& kualitatif. Journal of Experimental Psychology: General.

Sugiyono. (2016). metodologi penelitian kuantitatif kualitatif dan R \& D. In Bandung: Alfabeta. https://doi.org/10.1164/rccm.200409-1267OC

Suwadji. (2015). Manajemen Peningkatan Mutu Berbasis Pondok Pesantren. Edukasi.

Syafroni Ladzi. (2012). Manajemen dan Reformasi Pelayanan Publik dalam konteks birokrasi Indonesia. Aditya Media.

Tepy, N. R. T. (2017). STRATEGI PENGELOLAAN SEKOLAH TINGGI BERASRAMA DI KABUPATEN SEMARANG. Kelola: Jurnal Manajemen Pendidikan. https://doi.org/10.24246/j.jk.2016.v3.i1.p98-114

Usman, H. (2012). Manajemen teori, praktik dan riset pendidikan. In PT. Remaja Rosdakarya.

Wahyudin, D. (2014). Manajemen Kurikulum (Cetakan 1). Bandung: PT Remaja Rosdakarya.

Yakin, N. (2016). Studi Kasus Pola Manajemen Pondok Pesantren Al-Raisiyah di Kota Mataram. Ulumuna. https://doi.org/10.20414/ujis.v18i1.159

Yatimah, D. (2011). Manajemen Pendidikan Pesantren dalam Upaya Peningkatan Mutu Santri. Jurnal El-Hikmah Fakultas Tarbiyah UIN Maliki Malang.

Yin, J. Z., Feng, Y. M., Wu, S. X., Zhang, X. H., Wang, S. M., Wang, Q., ... Qi, D. L. 
(2014). Assessment of the iodine status of the Wa national boarding school students in southwest China. Biological Trace Element Research. https://doi.org/10.1007/s12011-014-0072-y

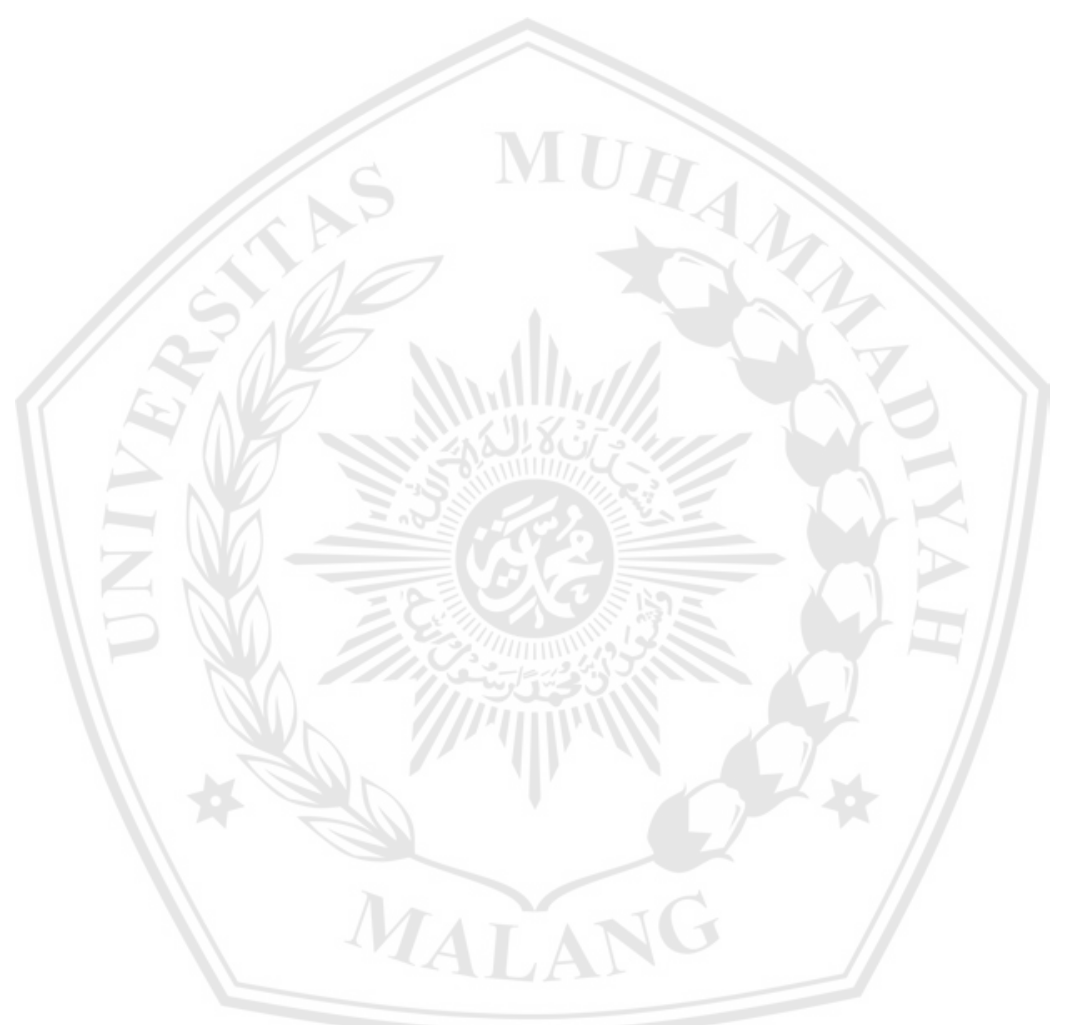

